\title{
Adolescent health promotion based on community-centered arts education
}

\author{
Promoção da saúde do adolescente baseada na arte/educação e centrada na comunidade \\ Promoción de la salud del adolescente basada en el arte/educación y centrada en la comunidad
}

\section{Anny Giselly Milhome da Costa Farre","I, Patrícia Neyva da Costa Pinheiro", Neiva Francenely Cunha Vieira", Fabiane do Amaral Gubert", Maria Dalva dos Santos Alves", Estela Maria Leite Meirelles Monteiro"II \\ ' Universidade Federal de Sergipe, Department of Nursing. Lagarto, Sergipe, Brazil. \\ "Universidade Federal do Ceará, Faculty of Pharmacy Dentistry and Nursing, Postgraduate Program in Nursing. Fortaleza, Ceará, Brazil. \\ II' Universidade Federal de Pernambuco, Center for Health Sciences, Department of Nursing. Recife, Pernambuco, Brazil.}

How to cite this article:

Farre AGMC, Pinheiro PNC, Vieira NFC, Gubert FA, Alves MDS, Monteiro EMLM. Adolescent health promotion based on community-centered arts education. Rev Bras Enferm [Internet]. 2018;71(1):26-33.

DOI: http://dx.doi.org/10.1590/0034-7167-2016-0078

Submission: 04-01-2016 Approval: 03-03-2017

\begin{abstract}
Objective: To evaluate the contribution of arts education to health promotion of adolescents in situations of urban social vulnerability. Method: Participatory evaluative research, with a qualitative approach, using as a reference the theoretical constructs of Paulo Freire's Conscientization and the Empowerment Evaluation as a method of collecting with adolescents and teachers of an arts education program in the field of the Family Health Strategy. Results: Participants constructed a collective mission that represented the concept of adolescent health promotion. Arts education activities were prioritized and ranked with a mission focus, and over a three-month period, the program implemented health goals through art. In the reevaluation, the group presented a broad look at the implementation of activities and self-determination for change. Final considerations: Arts education is a potential space for nurses to act in the conscientization and empowerment of adolescent health in Primary Health Care.
\end{abstract}

Descriptors: Health Education; Adolescent; Health Promotion; Community-Based Participatory Research; Conscientization.

\section{RESUMO}

Objetivo: Avaliar as contribuições da arte/educação para a promoção da saúde de adolescentes em situação de vulnerabilidade social urbana. Método: Pesquisa avaliativa, participativa, abordagem qualitativa, que utilizou como referencial os constructos teóricos de Conscientização de Freire e como método de coleta a Avaliação de Empoderamento com adolescentes e professores de um programa de arte/educação no território da Estratégia de Saúde da Família. Resultados: Os participantes construíram uma missão coletiva que representou o conceito de promoção da saúde do adolescente. As atividades de arte/educação foram priorizadas e classificadas com foco na missão, e, durante um período de três meses, o programa implementou metas na saúde por meio da arte. Na reavaliação, o grupo apresentou um olhar ampliado acerca da execução das atividades e autodeterminação para mudanças. Considerações finais: A arte/educação foi um potencial espaço para atuação do enfermeiro na conscientização e empoderamento em saúde do adolescente na Atenção Básica à Saúde.

Descritores: Educação em Saúde; Adolescente; Promoção da Saúde; Pesquisa Participativa Baseada na Comunidade; Conscientização.

\section{RESUMEN}

Objetivo: evaluar las contribuciones del arte/educación para la promoción de la salud de adolescentes en situación de vulnerabilidad social urbana. Método: pesquisa evaluativa, participativa, abordaje cualitativa, que utilizó como referencial los constructos teóricos de Concientización de Freire y como método de colecta a Evaluación de Empoderamiento con adolescentes y profesores de un programa de arte/educación en el territorio de la Estrategia de Salud de la Familia. Resultados: los participantes construyeron una misión colectiva que representó el concepto de promoción de la salud del adolescente. Las actividades de arte/educación fueron priorizadas y clasificadas con foco en la misión y durante un período de tres meses el programa implementó metas en la salud por medio del arte. En la reevaluación, el grupo presentó una mirada ampliada acerca de la ejecución de las actividades y 
autodeterminación para cambios. Consideraciones finales: el arte/educación fue un potencial espacio para actuación del enfermero en la concientización y empoderamiento en salud del adolescente en Atención Básica a la Salud.

Descriptores: Educación en Salud; Adolescente; Promoción de la Salud; Pesquisa Participativa Basada en la Comunidad; Concientización.

\section{INTRODUCTION}

The Estratégia Saúde da Família [Family Health Strategy] (FHS) is the structuring axis for the expansion and consolidation of Primary Health Care (PHC) in Brazil. The FHS can be understood as an emerging health care model in which professionals develop health care for families, groups and sociocultural communities, with an ethical commitment to collaborate to change the Biomedical paradigm for Health Promotion (HP) ${ }^{(1)}$.

Currently, the Brazilian teenager is a target public for the elaboration of HP public policies aimed at the achievement of the millennium goals, since adolescence is considered a window of opportunity for becoming a healthy and productive adult. However, this phase is also seen as a period of vulnerability, since the individual faces a series of risk situations that may generate immediate or future health problems ${ }^{(2)}$.

These risks can be seen, especially in large urban centers, where there are fragile family structures, with young people who prefer the space of the streets rather than the home and experience living conditions limited by the socioeconomic context. Conflicts, frustrations and vulnerabilities arise in the lives of adolescents who do not find a path to a prosperous future ${ }^{(3)}$.

In this context, nurses working in urban FHS play an important role as a health educator: to enable adolescents to find a healthier path between social risks and vulnerabilities, and to strengthen youth empowerment and resilience to cope with adversity.

Health education is one of the main components of Nursing care. The purposes and benefits of caring become the same as educating, insofar as they both increase people's autonomy for health self-management ${ }^{(4)}$. The nurse provides care while educating, and for that must be aware of the latest educational possibilities and base their practice on scientific evidence.

Studies have presented arts education as a strategy promoting adolescent health, in which art has been able to arouse interest and participation in the educational process, as well as to instigate creativity and stimulate reflections on the daily life of adolescents ${ }^{(5-6)}$.

Education through art or arts education is any and all conscious work to develop the relationship of audiences with art. It is an important tool for the development of perception, imagination and critical capacity; in this way, it allows people to analyze perceived reality and develop creativity in a way that can lead to change ${ }^{(7)}$.

In this sense, the following question emerged: could arts education contribute to the process of conscientization and empowerment in the health of adolescents in situations of urban social vulnerability?

The present research considered conscientization (critical consciousness) as the critical development of becoming aware through an inexhaustible movement of apprehension of reality, reflection and transformation. It is an act of knowing oneself and the world; it is the most critical look possible at reality ${ }^{(8-9)}$. And empowerment is considered as a sociocultural process of building and strengthening self-determination for change in health ${ }^{(10-11)}$.

\section{OBJECTIVE}

To evaluate the contributions of arts education to the promotion of adolescent health in situations of urban social vulnerability.

\section{METHOD}

\section{Ethical aspects}

The research project was submitted and approved by the Research Ethics Committee of the Federal University of Ceará. Throughout the text, the subjects' statements were identified by the letter A (adolescent), followed by identification number ( 1 to 21), gender $M$ (male) or $F$ (female) and age of the participant or letter $\mathrm{E}$ (arts educators), followed by the identification number (1 to 5). Two community residents mentioned by the participants during the speeches received the pseudonyms João da Esquina and Jovem Luke, to preserve the anonymity of the study scenario.

\section{Theoretical-methodological reference and type of study}

Evaluative, participatory research, with a predominantly qualitative approach, using Paulo Freire's Conscientization constructs $^{(8-9)}$ and Fetterman's Empowerment Assessment (EA) $)^{(10-11)}$ as a theoretical-methodological reference.

The Conscientization movement is characterized by the degree of man's awareness of the problems of his time and space. According to Freire, a man can move from intransitive consciousness to transitive-naive and to criticism, in the direction of a magical or naive view of the world to a more searching, critical view, with a commitment to change. The movement is characterized by the amplification of the power of capturing reality and the dialogue of man; concerns and individual interests are expanded to the world, and knowledge of past history is needed to understand the present ${ }^{(9)}$.

The EA is a participatory process that uses concepts, techniques and evaluative findings to promote self-determination (empowerment) of people and, consequently, generate improvements in projects, programs and other social technologies. It aims to help people evaluate their own programs through three integrated stages: 1) Construction of the Mission; 2) Assessment of the current situation; 3) Planning for the future. The evaluator has an active role in this process and plays the role of facilitator for the group, a critical friend of the program ${ }^{(10-11)}$. The researchers performed an adaptation of the method to obtain more evaluative/comparative data of the changes generated and included two final stages: 4) Implementation/monitoring; 5) Reevaluation. 


\section{Methodological procedures}

\section{Study scenario}

The study was developed in one of the centers of a governmental arts education program for children and adolescents in situations of urban social vulnerability in the state of Ceará, Brazil, This institution is maintained by the Municipality of Fortaleza with the objective of promoting and disseminating Citizenship and community well-being.

The priority public of this program was children and adolescents victims of sexual violence, living on the streets and/or drug addicts and in compliance with socio-educational measures in an open regime, sent by social or judicial services. Volunteer membership was also an entry option when openings were available to the community in general.

The adolescents participated in arts education workshops in the artistic language of dance, visual and audiovisual arts, as well as recreational and sports activities, which took place from Monday to Friday, before or after frequenting school, with an average duration of four hours per day. The total program lasted two years, and approximately 50 adolescents were linked to the artistic activities conducted by five arts educators, who had the support of a multi-professional socio-educational team.

The program agreed to carry out field research activities articulated to the arts education workshops from July to November 2013.

\section{Data source}

The research was widely disseminated in the institution through meetings and folders to sensitize the field. A period of voluntary enrolment was opened for those interested in participating in the research, and at the time, 28 adolescents and five arts educators were enrolled.

The researchers established the following inclusion criteria for adolescents: age group of 12 to 18 years, to be linked to the program for at least six months and a maximum of one year, to regularly attend arts education workshops, to have parental consent or from legal guardian. While the criterion for arts educators was to be linked to the program for at least six months.

A total of 21 teenagers and five arts educators were selected for the research and regrouped in new classes of dance, visual arts and audiovisual workshops according to personal preference.

\section{Data collection and organization}

The art workshops took place normally during the fivemonth period of data collection; however, six open group sessions $^{(10)}$ were conducted by the researchers to introduce and/ or finalize the five stages of EA.

Chart 1 describes the research stages, division of the meetings, axis of the discussion and the final product of the stages.

In the first stage of the EA, the participants elaborated a unified proposal for the health promotion of adolescents in the program. The mission was constructed from key phrases derived from the reflection on provocative existential situations $^{(12)}$ illustrated in an artistic model produced by the group.

In the second stage, the group listed 14 arts education activities developed in the program, considered important for the achievement of the mission, and prioritized ten of these through a vote. Participants then assigned scores for the selected activities on a scale from 1 (poor) to 10 (excellent), considering how well this item was being developed in the program to promote the health of its members. A large voting panel was generated, and the group discussed the differences and motivations of the scores, as well as visualized the average scores calculated for each activity, which reflected the current status ${ }^{(13)}$ of health promotion in the program.

In the third stage of the evaluation, the group selected the activities that received lower averages in the general context, since these would require improvement ${ }^{(11)}$. Thus, the group chose the activities with lower averages in each artistic language (dance, visual arts and audiovisual) and elaborated plans of action for the three-month period, including goals, strategies and markers of improvement.

Chart 1 - Stages in the evaluation of Empowerment as developed and adapted in the study, Fortaleza, Ceará, Brazil, 2014

\begin{tabular}{|c|c|c|c|}
\hline Stage & $\begin{array}{l}\text { Session } \\
\text { or period }\end{array}$ & Axis of discussion & Final product \\
\hline \multirow{2}{*}{$\begin{array}{l}1^{\text {a }} \begin{array}{l}\text { Construction } \\
\text { of the mission }\end{array}\end{array}$} & Meeting 1 & Problematization of health reality & Artistic model of the social reality of health \\
\hline & Meeting 2 & Contextualization of Health goals & Collective phrase to represent the mission \\
\hline \multirow{2}{*}{$\begin{array}{ll}2^{a} & \text { Assessment of } \\
& \text { current situation }\end{array}$} & Meeting 3 & Prioritization of arts education activities & List of health promotion activities \\
\hline & Meeting 4 & Classification of arts education activities & Evaluation panel with individual and collective notes \\
\hline $3^{a}$ Planning for the future & Meeting 5 & Classification of arts education activities & Plan of action for the 3-month period \\
\hline $\begin{array}{ll}4^{\mathrm{a}} & \begin{array}{l}\text { Implementation and } \\
\text { monitoring }\end{array}\end{array}$ & 3 months & $\begin{array}{l}\text { Implementation of the action plan and } \\
\text { adaptation to program resources }\end{array}$ & Artistic creations as evidence of goal achievement \\
\hline $5^{\mathrm{a}}$ Reevaluation & 6 months & Reclassification of arts education activities & New evaluative panel with individual and collective scores \\
\hline
\end{tabular}


The implementation and monitoring of the plan of action were developed in the fourth stage of the research, over a period of three months, during the arts education workshops themselves. The researchers acted as critical-friends ${ }^{(10)}$ of the program and assisted the arts educators in guiding the workshops to reach the goals. The plans were revised and adapted to the financial and material resources of the program.

In the last step, the participants reassessed all ten arts education activities with the assignment of scores from 1 to 10 , generating a comparative picture of the means before and after the application of EA.

The researchers recorded the data collected in field diaries, made audio and/or video recordings of the group sessions with subsequent transcription of dialogs and photographed the artistic productions. The end-products of each step were stored in the evaluative record of the research.

\section{Data analysis}

The data were organized into five thematic categories based on the stages of empowerment assessment: Mission Construction; Current situation; Planning for the future; Implementation/monitoring; and Reevaluation.

The evaluation panels generated quantitative data (notes and averages) that were grouped in graphs; and qualitative data (testimonials) that were inserted in the text to justify the evaluations attributed by the participants, as well as being characterized as the main axis of the discussions.

\section{RESULTS}

\section{Construction of the mission}

After the process of problematization and contextualization of the adolescent health reality, the group constructed the collective mission, a unified purpose that represented the group's health wishes:

Continue to practice in social and family life the activities developed [in the program], as well as maintaining a balanced physical, mental and emotional health through good nutrition, friendships and respect, conscious and responsible for your own body and its limits. (Collective Construction)
In addition to the social context, the participants included the family context as a fundamental scenario for the promotion of adolescent health. Opinions about the scope of the mission reflected the difficulties in achieving this:

Aunty, it's going to be very difficult to achieve this mission, because the youngsters come here for the project and then they forget about everything, they go back to crime and trafficking, and there's no health like that, but it's the fault of the guys up there [politicians] the young man returns to the community. (A10, M, 17 years)

Here in the program young people make art, but they also work for citizenship. If they could bring to life all that we wrote in the mission, it would be very good. But that balance of physical and mental health is impossible in today's crazy life. (E3)

\section{Current situation}

The activities of arts education considered important for the achievement of the mission in order of priority/voting were: 1) Recreational Activities, 2) Cine Club, 3) Graffiti, 4) Relaxation, 5) Elongation, 6) 8) Choreography, 9) Photography, 10) Video Production, 11) Painting, 12) Handicrafts, 13) Sculpture, 14) Serigraphy. The first 10 activities were selected for the classification stage that generated the panel of Table 1.

In the overall vision of the group, the development of activities in the program and its contribution to the achievement of the mission was assessed as good or very good and on a scale of 1 to 10 , few participants attributed lower ratings.

The testimonies illustrated the justification for the high ratings:

Recreational activity is the best thing we do here, I love it, we have a lot of fun, it's good, it's happy. Grade 10. (A21, $\mathrm{F}, 14$ years)

When you have graffiti, my imagination goes a long way ... I get a good head thinking of a good thing. I love graffiti. Cool! (A4, M, 16 years)

Everything here is great. I gave 10 for everything, because I think that the way it is happening is very worthwhile for the health of the guys here. (E4)

Table 1 - Panel of scores attributed by the participants in the classification of the arts education activities, Fortaleza, Ceará, Brazil, 2014

\begin{tabular}{|c|c|c|c|c|c|c|c|c|c|c|c|c|c|c|c|c|c|c|c|c|c|c|c|}
\hline \multirow{2}{*}{ Activities } & \multicolumn{22}{|c|}{ Identification and scores of the participants } & \multirow{2}{*}{ Mean } \\
\hline & A1 & A2 & A3 & A4 & A5 & A6 & A7 & A8 & A9 & A10 & A11 & A12 & A13 & A14 & A15 & A16 & A17 & E1 & E2 & E3 & E4 & E5 & \\
\hline Recreation & 10 & 10 & 7 & 10 & 10 & 10 & 10 & 10 & 10 & 10 & 9 & 9 & 10 & 10 & 10 & 10 & 10 & 10 & 7 & 10 & 10 & 10 & 9.6 \\
\hline Cine Club & 10 & 10 & 10 & 9 & 9 & 7 & 10 & 9 & 10 & 9 & 10 & 7 & 10 & 10 & 10 & 10 & 9 & 7 & 5 & 8 & 10 & 10 & 9.0 \\
\hline Video & 10 & 10 & 6 & 9 & 7 & 8 & 8 & 10 & 10 & 9 & 9 & 8 & 10 & 10 & 8 & 7 & 10 & 8 & 8 & 6 & 10 & 10 & 8.6 \\
\hline Photography & 10 & 10 & 10 & 5 & 8 & 8 & 7 & 7 & 10 & 10 & 10 & 10 & 10 & 3 & 8 & 9 & 10 & 6 & 10 & 8 & 10 & 10 & 8.5 \\
\hline Graffiti & 10 & 10 & 10 & 9 & 7 & 10 & 10 & 10 & 10 & 8 & 10 & 9 & 10 & 10 & 8 & 9 & 10 & 7 & 10 & 7 & 10 & 10 & 9.2 \\
\hline Drawing & 10 & 10 & 9 & 9 & 8 & 9 & 9 & 10 & 10 & 7 & 10 & 10 & 10 & 10 & 8 & 8 & 8 & 8 & 10 & 7 & 10 & 8 & 9.0 \\
\hline Relaxation & 5 & 10 & 8 & 8 & 10 & 8 & 9 & 8 & 10 & 9 & 10 & 10 & 9 & 4 & 10 & 10 & 9 & 9 & 8 & 10 & 10 & 10 & 8.8 \\
\hline Elongation & 8 & 8 & 6 & 4 & 10 & 9 & 9 & 10 & 9 & 7 & 10 & 9 & 9 & 8 & 10 & 10 & 10 & 9 & 8 & 10 & 10 & 10 & 8.7 \\
\hline Physical stamina & 8 & 7 & 10 & 5 & 10 & 9 & 10 & 10 & 10 & 10 & 10 & 8 & 9 & 10 & 9 & 10 & 10 & 10 & 7 & 10 & 10 & 10 & 9.1 \\
\hline Choreography & 10 & 9 & 7 & 9 & 10 & 10 & 7 & 10 & 8 & 8 & 9 & 10 & 9 & 5 & 10 & 10 & 10 & 8 & 10 & 10 & 10 & 8 & 8.9 \\
\hline Individual Mean & 8.5 & 9.4 & 8.3 & 7.7 & 8.9 & 8.8 & 8.9 & 9.4 & 9.7 & 8.7 & 9.7 & 9.0 & 9.6 & 8.0 & 9.1 & 9.3 & 9.6 & 8.2 & 8.3 & 8.6 & 10 & 9.6 & 8.9 \\
\hline
\end{tabular}


Some participants gave lower marks, considering the material resources of the program:

I gave 3 for photography, because there is no camera to take pictures with, the teacher has to bring one from home. Only that. And I gave 4 in relaxation, because I could not stay calm on the day I did relaxation. (A14, M, 16 years)

Look, Auntie, it's very difficult for us to work with photo and film. It needs computers and other things, things we do not have here, so it gets difficult, how can it be good for health if we have these problems? (A3, F, 13 years)

The final averages of arts education activities are presented in descending order in Figure 1.

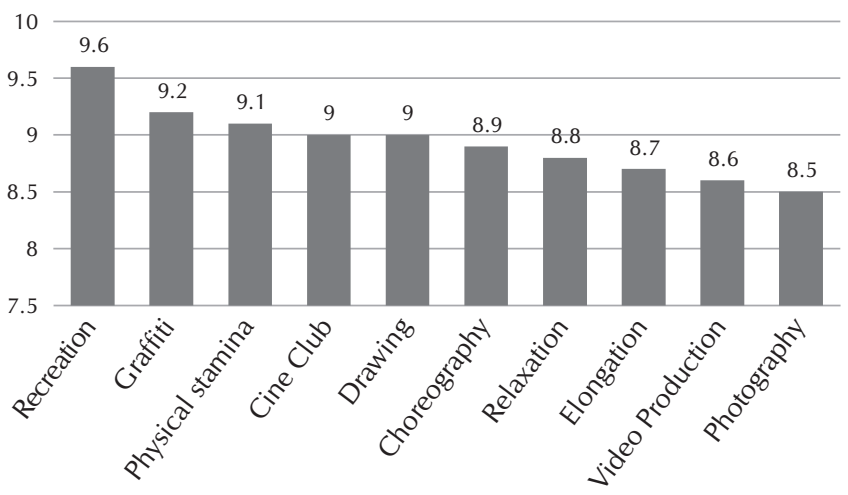

Figure 1 - Representation in decreasing order of the mean values for the arts education activities, Fortaleza, Ceará, Brazil, 2014

The selected activities with lower averages according to artistic languages were: a) Audiovisual: Photography; B) Dance: Elongation; C) Visual Arts: Drawing and Graffiti. Participants indicated the need for improvements in these areas and considered the importance of implementing the promotion of adolescent health in the development of artistic activities.

\section{Planning for the future}

The plans of action were elaborated with the following goals in the activities of arts education: a) Photography: to work the reality behind the image; B) Elongation: improve group dedication and effort; know the functioning of the female body; C) Drawing and Graffiti: Working on the theme of drugs and friendships in the community.

The group proposed to approach each monthly plan of action according to the execution of each artistic workshop and outlined various strategies such as: registering images of the daily life of the neighborhood, obtaining material resources that are missing from the program, organizing artistic events in the community, improve the students nutrition, work the body and its limits in health, produce cards and pamphlets with drawings, and paint graffiti with positive messages onto walls.

\section{Implementation and monitoring}

Over the course of three months, the plans of action were modified and implemented through three strategies that integrated all the artistic workshops: Sidewalk Chat, Poetic Narrative Exercise and Health Chat.

First, teens collected the history of the neighborhood, recorded images and identified prominent characters in the community, such as João da Esquina, one of the community's oldest residents, and Jovem Luke, an example of resilience, a former participant in the program and who managed to overcome the situation of social vulnerability experienced in the neighborhood.

The "sidewalk chat" was an open event held on the sidewalk of the space and the program was developed with the participation of local residents. The adolescents presented exhibitions of drawings about drugs and violence, presented street theater and heard the life stories of João da Esquina and Luke. The testimonies reflected this stage of reflection:

Auntie, I know it's important to study and not fall into drugs, we know there are people who have managed to be someone in life like 'Luke', I want to be a doctor someday. (A1, M, 15 years)

'Luke' made me very happy. I want to be like him, an artist, but I do not want to live in another place, I love my neighborhood, I have my friends here. (A13, M, 15 years)

The "narrative of poetic exercise" represented the collective construction of a story about the past, present and future of the community through the encounter of generations. The story was transformed into a short film about the neighborhood, with the following skit:

The grandfather in his 80 s tells his life story to his grandson presenting what he has experienced since he was a child, his memories, experiences, loves, anguish, and situations that were funny and unusual in the neighborhood in which he grew up. The curious grandson mirroring himself in his grandfather, also recounts his achievements and challenges in the modern and contemporary Bela Vista neighborhood. The two dream together about how to transform and approach their own lives as they also transform their community. (Collective Construction)

In "health chat" the researchers participated in rounds of conversations with adolescents about sexual and reproductive health that were also related to their social context:

The girl loves a drug dealer and does everything for him. Then she gets pregnant and will suffer for the rest of her life. (A9, M, 12 years)

Auntie, for example, I knew I had to use a condom, but I had smoked marijuana and it happened. Then my son was born, I had to go to work to support him, I stopped studying, and I got involved with other stuff there and now I have to be here on the project. (A14, M, 16 years)

At the end of three months, the group organized a photographic exhibition open to the community, and, below each image, they wrote short critical stories about the health reality.

\section{Reevaluation}

The ten arts education activities were reevaluated, and most of the grades attributed by the participants were lower than in 
the previous evaluation, generating the comparative means chart in Figure 2.

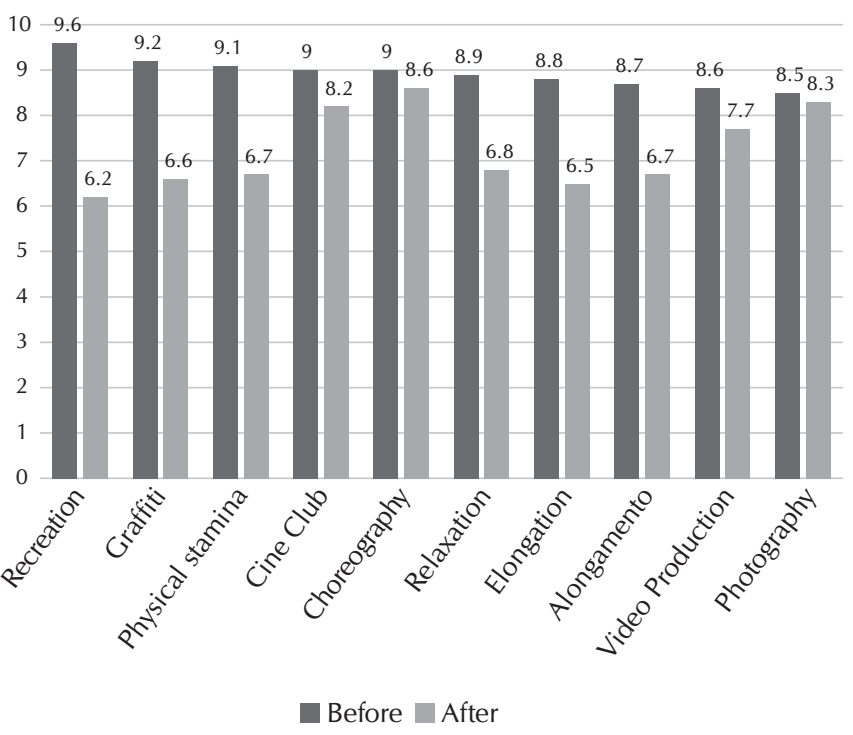

Figure 2 - Comparison of the mean scores for arts education activities before and after the implementation/ monitoring period of the plan of action, Fortaleza, Ceará, Brazil, 2014

In the course of the discussions, the participants justified the reduction of activity scores:

I thought that everything was good for our health, but now we see that it needs to improve a lot. The workshops are good for us, but it's not all 10 as I thought. Many of my friends left the project; we improvise with what they have [...]. (A11, F, 11 years)

I say the following [...] we did a lot in these three months and realized that we can change things, just work together. I'm not talking about asking for sponsorship, but ask the City Hall to give us the material we need to work. If the project exists, it must have material. (E3)

The activities that suffered major reductions in the value of the averages were not carried out in the period, as in the case of graffiti (from 9.2 to 6.6), because the group could not acquire painting material; and in the case of recreation (from 9.6 to 6.2) and dance activities (physical stamina, choreography, relaxation and elongation), which were not performed due to prioritization of other activities in the program.

\section{DISCUSSION}

The mission built by the group represented a new health reality to be achieved, a challenge for the problems related to the "streets" of the major Brazilian capitals. In low-income communities, approximately $17.7 \%$ of young people are exposed to violence, $13.5 \%$ of them abuse alcohol, $28.3 \%$ illicit drugs and $23.9 \%$ have had access to a firearm ${ }^{(14)}$. The economic conditions and unemployment due to low educational level are determinants of this scenario; nevertheless, the search for self-esteem, the absence of a father figure, the visibility before the community and dazzle in acquiring consumer goods are dangerous attractions for young people $\mathrm{e}^{(15)}$.

The articulation of the social environment with the family was a marked characteristic of the group, which recognized family coexistence as fundamental for health promotion. A nuclear family, with healthy behavior among its members, can be a protective factor in adolescents' health, especially for prevention of tobacco, alcohol and other drug use $\mathrm{e}^{(16)}$.

The majority of participants stated that it is impossible to achieve the mission in a world that leads young people to drugs and crime, in which the individual has little to contribute to change, and blame for the situation is directed onto the government. It was observed that naïve-transitive consciousness is characterized by simplicity in the interpretation of problems, by the underestimation of ordinary man's power, by hopelessness. The process of conscientization invites people to take a utopian view of the world ${ }^{(8)}$.

The meeting of the adolescent with a utopian world was influenced by the encounter of art with education in the generation of experiences that transformed the relations of being in the world through sensitivity, creativity and expression ${ }^{(7)}$. The prioritization stage of the activities represented the importance of joy and wellbeing for adolescents in the daily practice of arts education, as in the leisure activities and in the cine club.

On assigning scores, most participants only considered the existence of the activity in the program and not factors that could influence its appropriate development. That is, it was sufficient that the activity was happening so that it could contribute to the promotion of adolescent health.

Socio-educational programs developed in contrast to school based have a direct impact on the promotion of personal and social skills of children and adolescents. Via a meta-analysis, a study revealed significant improvements in social behavior, self-perception and school performance among the participants, as well as a reduction in behavioral problems compared to control groups ${ }^{(17)}$.

However, commonly in Brazil, social institutions that support atrisk-adolescents face problems, such as a lack of material, technical and human resources, thereby limiting the quality of service provided and distancing it from the planning and expected results ${ }^{(18)}$. This fact was initially observed by few participants of the study.

The activities selected for implementation of the goals (photography, dance-elongation, drawing and graffiti) have proved to be effective resources for the recovery of adolescents' protagonistic status and for stimulating critical reflections on health promotion, respectively, in the use of the "photo-voice" strategy ${ }^{(19)}$, the Practical Program of Educational Dance (PPDE) ${ }^{(5)}$ and drawing/expression ${ }^{(20)}$.

The health promotion strategies developed in arts education activities represented the artistic encounter of the past with the present in the community. Through a sense of historical perspective, the adolescent was able to increase awareness of the problems of his/her time and space, considering that there is no actuality that is not a historical process ${ }^{(9)}$.

The meeting of the present with the future of the adolescent was characterized by a feeling of belonging to the community, reinforced by the example of a young man's resilience. From the incorporation of the individual's belonging to a place, the 
process of constructing an imaginary identity begins, and even in situations of conflict, the person who has roots remains and fights for his place ${ }^{(21)}$. Motivation to overcome social adversities is characteristic of youthful resilience, even if adolescents experience poverty, health problems and conflicting family relationships, they can better cope with changes and promote positive mental health ${ }^{(16-17)}$.

In the health chats, sexuality was related to drug use, fascination with the financial power of trafficking, and the risks of unprotected practices. Adolescents who use illicit drugs are generally more susceptible to unprotected sex because, when using psychoactive substances, they engage more readily in situations of risk ${ }^{(22)}$. In this sense, health professionals can interact with risk groups in the community to identify social vulnerabilities and stimulate the young person's creative potential in developing innovative health practices ${ }^{(23)}$ and coping with drugs.

After experiencing the entire implementation process, participants re-evaluated arts education activities and gave lower scores than previously. This fact was related to a more critical evaluative vision that was directed to quality in the development of the activities and not simply to their existence. The recognition of the local possibilities for accomplishment of arts education activities drove the group as a protagonist, but necessarily did not exempt the program's role of resources provider to ensure continuity of the arts education workshops.

From Freire's theoretical framework ${ }^{(8-9)}$, it can be inferred that, as the adolescent moves from naïve-transitive to critical consciousness, he/she expands the power to capture health reality and ability to critically discuss the promotion of health in arts education activities.

The evaluation process has strengthened the self-determination of program members to achieve local improvements in the short term, but will need to be continuously exercised in order to generate individual and collective change in the medium and long term.

\section{Study limitations}

The main limitations and challenges of the study are related to the application of EA in the Brazilian context of a public institution and its developments: limited material resources available for arts education workshops, reduction in the number of participants who remained linked to the program in the reevaluation stage and culture of fear of the institution to participate in an evaluation process. These facts limited the achievements of the mission and some goals outlined, however, they generated sociopolitical reflections within the group.

The authors consider that the three-month period was a minimum time for implementation/monitoring of goals, and recommend that further studies should extend this stage in the search for other results and with a larger number of participants.

\section{Contribution to Nursing, health or public policy}

The study strengthened the ten principles of EA that can be applied to the construction of adolescent health programs and policies in Brazil: 1. Improvement; 2. Community ownership; 3. Inclusion; 4. Democratic participation; 5 . Social justice; 6. Knowledge of the community; 7 . Evidence-based strategies; 8. Training; 9. Organizational learning; 10. Responsibility ${ }^{(10-11)}$.

The arts education program evaluated was considered a potential space for health professionals to act in the conscientization and empowerment movement of adolescent health in the urban setting. The nurse working in Primary Health Care can identify spaces of artistic experiences in the communities and articulate health programs that will be attractive for adolescents. In this case, the nurse does not need to be an arts educator or an artist, because his/her role is of critical friend, consultant or health promoter who works in an interdisciplinary manner.

\section{FINAL CONSIDERATIONS}

The research presented a triad for the Promotion of Adolescent Health in situations of social vulnerability with the following components: individual, community and socio-educative support. Arts education was a potential space for nurses to act in the conscientization and empowerment of adolescent health.

In the urban setting, adolescents need self-determination to overcome economic barriers and face social risks in order to spend this period of life in a positive way. The socioeducational support services play a fundamental role in the community, as they represent spaces of experience that fill the chasm between school and the streets and can contribute to the promotion of physical and mental health of adolescents, especially by using critical-reflexive strategies, such as arts education.

In this study, the conscientization movement was articulated to the development of the stages of empowerment evaluation, which permeated changes in the participants' perspective on the reality of life and health. Initially, the group voiced feelings of impotence in the face of urban problems and evaluated the achievement of arts education activities as health promoters by the simple fact that they were being carried out in the community, characterizing a naive vision of the program.

Subsequently, the group voiced possibilities for individual and collective change, carried out artistic actions and considered the existence of failures in the development of arts education activities that compromised its educational and health promoting quality. Thus, the interests and concerns of the participants were expanding from the individual to the collective, critical, self-determining sphere for change in health.

\section{REFERENCES}

1. Fertonani HP, Pires DEP, Biff D, Scherer MDA. The health care model: concepts and challenges for primary health care in Brazil. Ciênc Saúde Colet[Internet]. 2015[cited 2016 Jan 10];20(6):1869-78. Available from: http://www.scielo.br/pdf/csc/v20n6/ en_1413-8123-csc-20-06-1869.pdf 
2. USA. United Nations Children's Fund. The state of the world's children 2011: adolescence an age of opportunity[Internet]. New York (NY): UNICEF; $2011[$ cited 2013 Jun 20]. Available from: https://www.unicef.org/sowc2011/pdfs/SOWC-2011-MainReport_EN_02092011.pdf

3. United Nations Children's Fund (US). The state of the world's children 2012: children in an urban world[Internet]. New York (NY): UNICEF; 2012[cited 2013 Jun 20]. Available from: https://www.unicef.org/sowc2012/pdfs/SOWC\%202012-Main\%20 Report_EN_13Mar2012.pdf

4. Martins PAF, Alvim NAT. Plano de cuidados compartilhado: convergência da proposta educativa problematizadora com a teoria do cuidado cultural de enfermagem. Rev Bras Enferm[Internet]. 2012[cited 2014 May 20];65(2):368-73. Available from: http:// www.scielo.br/pdf/reben/v65n2/v65n2a25.pdf

5. Costa AGM, Monteiro EMLM, Vieira NFC, Barroso MGT. A dança como meio de conhecimento do corpo para promoção da saúde dos adolescentes. J Bras Doenças Sex Transm[Internet]. 2004[cited 2013 Jun 12];16(3):43-6. Available from: http://www. dst.uff.br/revista16-3-2004/5.pdf

6. Guimarães JS, Lima IMSO. Educação para a saúde: discutindo uma prática pedagógica integral com jovens em situação de risco. Saude Soc[Internet]. 2012[cited 2014 May 20];21(4):895-908. Available from: http://www.scielo.br/pdf/sausoc/v21n4/v21n4a09.pdf

7. Barbosa AM. Arte/educação no Brasil. Coleção Debates. 7. ed. São Paulo: Perspectiva; 2012.

8. Freire P. Conscientização teoria e prática da libertação: uma introdução ao pensamento de Paulo Freire. 3.ed. São Paulo: Centauro; 2001.

9. Freire P. Educação e atualidade brasileira. São Paulo: Cortez; 2001.

10. Fetterman DM. Foundations of empowerment evaluation. Thousand Oaks: Sage, 2001.

11. Fetterman DM, Wandersman A. Empowerment evaluation principles in practice. Thousand Oaks: Sage; 2005.

12. Freire P. Pedagogia do oprimido. 50. ed. Rio de Janeiro: Paz e Terra; 2011

13. Fetterman DM, Wandersman A. Empowerment evaluation: yesterday, today, and tomorrow. Am J Eval[Internet]. 2007 [cited 2012 Aug 23];28(2):179-98. Available from: http://journals.sagepub.com/doi/pdf/10.1177/1098214007301350

14. Moreira DP, Vieira LJES, Pordeus AMJ, Lira SVG, Luna GLM, Silva JG, Machado MFAS. Exposição à violência entre adolescentes de uma comunidade de baixa renda no Nordeste do Brasil. Ciênc Saúde Col[Internet]. 2013[cited 2014 May 20];18(5):1273-82. Available from: http://www.scielo.br/pdf/csc/v18n5/12.pdf

15. Morais NA, Aquino MC, Reis S, Koller SH. Promoção de saúde e adolescência: um exemplo de intervenção com adolescentes em situação de rua. Psico Soc[Internet]. 2010[cited 2013 Jun 05];22(3):507-18. Available from: http://www.scielo.br/pdf/psoc/ v22n3/v22n3a11.pdf

16. Ewing BA, Osilla KC, Pedersen ER, Hunter SB, Miles JNV, D'Amico EJ. Longitudinal family effects on substance use among an atrisk adolescent sample. Addic Behav[Internet]. 2015[cited 2016 Feb 10];41(8):185-91. Available from: http://www.sciencedirect. com/science/article/pii/S0306460314003499

17. Durlak JA, Weissberg RP, Pachan M. A meta-analysis of After-School Programs that seek to promote personal and social skills in children and adolescents. Am J Community Psychol[Internet]. 2010[cited 2015 Jan 28];45(3-4):294-309. Available from: http:// www.flume.com.br/pdf/Durlak_A_meta-analysisof_after_school.pdf

18. Eurípedes SR, Reis NA, Silva SA, Borges MR, Silva FA. Workshops with teachers: health education for management with adolescents. Acta Paul Enferm[Internet]. 2012[cited 2013 Jan 22];25(spe2):169-74. Available from: http://www.scielo.br/pdf/ape/ v25nspe2/27.pdf

19. Costa AGM, Vieira NFC, Gubert FA, Ferreira AGN, Scopacasa LF, Pinheiro PNC. Imagens e concepções de adolescentes moradores de zona rural sobre saúde. Cad Saúde Pública[Internet]. 2013[cited 2014 Nov 22];29(8):1675-80. Available from: http://www. scielo.br/pdf/csp/v29n8/v29n8a19.pdf

20. Costa AGM, Luna IT, Silva AA, Mesquita JS, Pinheiro PNC, Vieira NFC. Percepção de saúde de adolescentes de comunidade rural: entre o ideal e o real. Rev Eletr Enferm[Internet]. 2013[cited 2014 Nov 22];15(4):870-7. Available from: https://www.fen.ufg.br/ fen_revista/v15/n4/v15n4a03.htm

21. Carneiro HF. Violência, culpa e ato: causas e efeitos subjetivos em adolescentes. Psicol Rev[Internet]. 2010[cited 2013 Jan 22];16(3)53756. Available from: http://periodicos.pucminas.br/index.php/psicologiaemrevista/article/view/P.1678-9563.2010v16n3p537/2228

22. Luna IT, Costa AGM, Costa MS, Alves MDS, Vieira NFC, Pinheiro PNC. Knowledge and prevention of Sexually Transmitted Diseases among homeless adolescent. Ciênc Cuid Saúde[Internet]. 2013[cited 2014 Jun 12];12(7):346-55. Available from: http:// periodicos.uem.br/ojs/index.php/CiencCuidSaude/article/download/18693/pdf_21

23. Ferreira Júnior AR, Barros EMA, Sousa RA, Souza LJE. Vivência de adolescentes em atividade de promoção da saúde. Rev Bras Enferm[Internet]. 2013[cited 2013 Nov 08];66(4):611-4. Available from: http://www.scielo.br/pdf/reben/v66n4/v66n4a23.pdf 